Plant Tissue Cult. \& Biotech. 22(2): 179-185, 2012 (December)

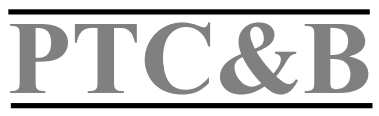

\title{
Micropropagation of Clerodendrum serratum L. through Direct and Indirect Organogenesis
}

\author{
S.M. Vidya ${ }^{*}$, V. Krishna ${ }^{1}$, B.K. Manjunatha ${ }^{2}$ and Pradeepa \\ Department of Biotechnology, NMAM Institute of Technology, Nitte, Karkala, Udupi \\ Dist., Karnataka-574 110, India
}

Key words: Clerodendrum serratum, Micropropagation, LM media, Microshoots

\begin{abstract}
In vitro clonal propagation of Clerodendrum serratum L., a rare medicinal plant has been reported by using LM medium supplemented with different growth hormones. The maximum number of shoots with maximum length were obtained from stem derived callus on LM media fortified with $1.5 \mathrm{mg} / \mathrm{l} \mathrm{BAP}$ and $0.3 \mathrm{mg} / \mathrm{l} \mathrm{NAA}$. Nodal explants showed direct organogenesis on LM media containing BAP $(0.5 \mathrm{mg} / \mathrm{l})$ alone. The regenerated shoots were successfully rooted with maximum frequency $(100 \%)$ on half strength LM media supplemented with $0.5 \mathrm{mg} / \mathrm{l} \mathrm{NAA}$. The well rooted microshoots were successfully transferred to hardening and survival rate was $88 \%$.
\end{abstract}

\section{Introduction}

Clerodendrum serratum L. is a member of Verbenaceae distributed in the deciduous forests of the Western Ghats of India (Saldanha and Nicolson 1976). As per the traditional claims roots are the potential source of drugs and it is used for various medicinal trails. Ethno-medicinal importance of the plant has been reported in various indigenous systems of medicines like Ayurveda, Siddha and Unani for the treatment of various life-threatening diseases such as syphilis, typhoid, cancer, jaundice and hypertension (Mukesh et al. 2012). The root bark extract of C. serratum contains D-mannitol, stigmasterols, three triterpenoids such as oleanolic acid, queretaric acid and cerratagenic acid (Banarjee et al. 1969). The plant was investigated for its potential activity viz., anti-inflammatory, analgesic, antipyretic activity (Vishwanathan 1999) and hepatoprotective activity (Vidya et al. 2007). Natural population of the plant species is decreasing due to habitat destruction, over exploitation along with poor seed setting and poor seed

*Author for correspondence: <drvidyasm@gmail.com>. ${ }^{1}$ Department of PG Studies and Research in Biotechnology and Bioinformatics, Jnanasahyadri, Kuvempu University, Shimoga, Karnataka-577 451, India. 'Department of Biotechnology, Oxford College of Engineering, Bommanahalli, Bangalore, Karnataka-560 068, India. 
germination. In vitro plant propagation is the promising technology for conservation of rare and endangered plants as in the present study. A few reports for in vitro rapid clonal propagation of $C$. serratum employing nodal stem segments are available (Sharma et al. 2008, Vidya et al. 2005). The present study describes the maximization of shoot multiplication through in vitro propagation of C. serratum by using LM growth medium fortified with different growth regulators.

\section{Materials and Methods}

Fruits of $C$. serratum L. were collected from the Lakkavalli Reserve Forest of the Central Western Ghats (Karnataka). Seeds were washed under running tap water, treated with $0.1 \%(\mathrm{v} / \mathrm{v})$ aqueous solution of Tween-20 (Hi-media, Mumbai) for $10 \mathrm{~min}$ and washed with distilled water five to six times. In a laminar air flow cabinet, seeds were immersed in $70 \%$ ethanol for $1 \mathrm{~min}$ and surface disinfected with an aqueous solution of $0.1 \% \mathrm{HgCl}_{2}$ for $10 \mathrm{~min}$. The disinfectant was removed by rinsing the material with sterilized cool distilled water five to six times. The seeds were inoculated on LM (Lloyd and McCown 1980) basal medium lacking hormone for eight weeks. The expanded young nodal segments and internodes were excised and inoculated aseptically on a sterilized LM medium fortified with different concentrations and combination of plant growth regulators such as BAP (1- $2.5 \mathrm{mg} / \mathrm{l})$ and NAA (0.1- $0.4 \mathrm{mg} / \mathrm{l})$ with $2 \%$ sucrose and gelled with $0.8 \%$ agar. The medium was supplemented with $0.1 \%$ casein hydrolysate, which served as a organic nitrogen source, $0.1 \%$ polyvinyl pyrrolidone (PVP) or $0.1 \%$ activated charcoal as an antioxidant. The $\mathrm{pH}$ of the media was adjusted to 5.8 and autoclaved. The cultures were incubated at $22 \pm 2^{\circ} \mathrm{C}$ under a $12 \mathrm{~h}$ photoperiod with 2000 Lux provided by a cool white fluorescent tube (Philips cool-white fluorescent tubes, India) with 65 to $70 \%$ relative humidity. Repeated subculturing was done at an interval of 15 days. For root induction, in vitro grown 45 days old microshoots were aseptically excised and transferred to half strength LM media supplemented with various concentrations of IBA, NAA and IAA. Rooted plantlets were removed from the culture, thoroughly washed and then transferred to pots containing sterilized garden soil. The regenerants were hardened for two weeks by covering them with a thin perforated transparent polythene bag to maintain humidity and were regularly watered with one-tenth strength of LM basal salt solution. After two weeks of incubation polythene bags were removed and the plants were exposed to natural condition. All experiments were repeated at least three times with ten replicates for each treatment. The effects of the treatments were assessed by comparison of the growth and development of shoots after four weeks with 
respect to the mean number of shoots per explant, mean length of shoots and frequency of shoot induction per explant. The mean number and length of shoots per explant was calculated at the end of 45 days of incubation. The results were subjected to statistical analysis using Tukey's multiple comparison.

\section{Results and Discussion}

The effect of BAP on shoot organogenesis was reported in Cleastrus paniculatus (Maruthi et al. 2004). In the present study the effect on multiple shoot induction by BAP and NAA at different concentrations was studied on in vitro derived stem as explants (Table 1, Fig. 1a). The callus initiation started at $1 \mathrm{mg} / \mathrm{l} \mathrm{BAP}$ and $0.1 \mathrm{mg} / \mathrm{l}$ of NAA and highest efficiency (91\%) was noted at $1.5 \mathrm{mg} / \mathrm{l}$ of BAP and $0.3 \mathrm{mg} / \mathrm{l}$ of NAA (Fig. 1b). Here differentiation of the shoot bud was noticed from the same media. An increase in the concentration of NAA favored only callus proliferation but hindered shoot differentiation potency of the callus. One of the possible roles of the lower level of auxin in the organogenic stage is to nullify the effects of cytokinin on shoot organogenesis and elongation. Reports of auxin and cytokinin combinations supporting organogenic differentiation have been well documented in Centella asiatica (Shashikala et al. 2005). In 15 days, stem callus showed initiation of small shoots from the nodular callus when it was subcultured in the same medium containing $1.5 \mathrm{mg} / \mathrm{l} \mathrm{BAP}$ and $0.3 \mathrm{mg} / \mathrm{l} \mathrm{NAA}$ (Fig. 1c). Initially, a single shoot elongated from the multiple shoot clusters and further proliferated within 30 days of incubation (Fig. 2a). The mean number of shoots obtained was $8.01 \pm 0.14$ with mean shoot lengths of $8.48 \pm 0.23 \mathrm{~cm}$ in 45 days old culture. Fig. $2 \mathrm{~b}$ shows significant difference in frequency of shoot regeneration and number of shoots per explant $(p<0.05)$. The synergic effect of cytokinin and low auxin for multiple shoot induction has been reported in the species of Santholina canescens (Casado et al. 2002).

The shoot regeneration efficiency of nodal explants for direct organogenesis was tested by different concentrations of BAP alone $(0.1-0.6 \mathrm{mg} / \mathrm{l})$. The in vitro derived nodal segments when placed on to the LM media supplemented with 0.5 $\mathrm{mg} / \mathrm{l} \mathrm{BAP}$ (Fig. 3a) produced shoot buds direct from the explants (Table 2). Initiation of shoot buds was noticed (Fig. 3b) within 15 days. In one month old culture a mean of $4.50 \pm 0.23$ shoots was formed with shoot length of $4.58 \pm 0.02$ $\mathrm{cm}$ (Table 2). In 45 days culture, the extensive elongation of multiple shoots was noticed (Fig. 3c). The results show the potential of the combined effect of BAP and NAA for shoot induction than BAP alone. Several reports agree the synergetic effect of higher concentration of cytokinin with lower concentration of auxin combination for better shoot organogenesis (Xie and Hong 2001). 
Table 1. Effect of BAP and NAA on callogenic and caulogenic responses from the stem explants of $C$. serratum.

\begin{tabular}{|c|c|c|c|c|}
\hline \multicolumn{2}{|c|}{$\begin{array}{l}\text { Growth } \\
\text { regulators (mg/l) }\end{array}$} & \multirow[t]{2}{*}{$\begin{array}{l}\text { Frequency of callus } \\
\text { induction }(\%)\end{array}$} & \multirow[t]{2}{*}{$\begin{array}{l}\text { Mean number of } \\
\text { shoots/callus }\end{array}$} & \multirow[t]{2}{*}{$\begin{array}{c}\text { Mean length of } \\
\text { shoots /callus } \\
(\mathrm{cm}) \\
\end{array}$} \\
\hline BAP & NAA & & & \\
\hline \multirow[t]{4}{*}{1.0} & 0.1 & 4 & $1.21 \pm 0.12$ & $1.29 \pm 0.03$ \\
\hline & 0.2 & 12 & $3.10 \pm 0.04$ & $2.01 \pm 0.18$ \\
\hline & 0.3 & 38 & $5.25 \pm 0.11$ & $4.39 \pm 0.11$ \\
\hline & 0.4 & 23 & $2.36 \pm 0.13$ & $3.11 \pm 0.13$ \\
\hline \multirow[t]{4}{*}{1.5} & 0.1 & 42 & $4.23 \pm 0.09$ & $3.20 \pm 0.51$ \\
\hline & 0.2 & 67 & $6.95 \pm 0.01$ & $6.32 \pm 0.19$ \\
\hline & 0.3 & 91 & $8.01 \pm 0.14^{*}$ & $8.48 \pm 0.23^{*}$ \\
\hline & 0.4 & 82 & $5.39 \pm 0.17$ & $6.90 \pm 0.21$ \\
\hline \multirow[t]{4}{*}{2.0} & 0.1 & 18 & $3.18 \pm 0.09$ & $3.17 \pm 0.14$ \\
\hline & 0.2 & 23 & $4.97 \pm 0.13$ & $3.97 \pm 0.17$ \\
\hline & 0.3 & 68 & $5.28 \pm 0.15$ & $5.23 \pm 0.20$ \\
\hline & 0.4 & 56 & $3.08 \pm 0.13$ & $2.18 \pm 0.06$ \\
\hline \multirow[t]{4}{*}{2.5} & 0.1 & - & - & - \\
\hline & 0.2 & - & - & - \\
\hline & 0.3 & - & - & - \\
\hline & 0.4 & - & - & - \\
\hline \multicolumn{5}{|c|}{ ANOVA } \\
\hline \multicolumn{2}{|c|}{ F } & & 18.7 & 45.20 \\
\hline \multicolumn{2}{|l|}{$\mathrm{df}$} & & 6,108 & 6,108 \\
\hline
\end{tabular}

Each value represents mean $\pm S E$ of ten observations. The ${ }^{*} \mathrm{p}$ value $<0.05$ was considered statistically significant.

Table 2. Effect of different concentrations of BAP on direct organogenesis from the nodal explants of $C$. serratum.

\begin{tabular}{lccc}
\hline $\begin{array}{c}\text { BAP } \\
(\mathrm{mg} / \mathrm{l})\end{array}$ & $\begin{array}{c}\text { Frequency of } \\
\text { regeneration }(\%)\end{array}$ & $\begin{array}{c}\text { Mean no. of } \\
\text { shoots/explant }\end{array}$ & $\begin{array}{c}\text { Mean length of shoots } \\
\text { /explant }(\mathrm{cm})\end{array}$ \\
\hline 0.1 & 10.05 & $1.05 \pm 0.23$ & $3.00 \pm 0.18$ \\
0.2 & 26.35 & $1.53 \pm 0.10$ & $3.65 \pm 0.03$ \\
0.3 & 58.5 & $2.28 \pm 0.28$ & $4.05 \pm 0.01$ \\
0.4 & 69.0 & $3.30 \pm 0.30$ & $4.30 \pm 0.04$ \\
0.5 & $77.8^{*}$ & $4.50 \pm 0.23^{*}$ & $4.58 \pm 0.02^{*}$ \\
0.6 & 69.2 & $3.00 \pm 0.52$ & $3.01 \pm 0.05$ \\
ANOVA & & & 113.2 \\
F & & 38.29 & 5,54 \\
df & & 5,54 & \\
\hline
\end{tabular}

Each value represents mean $\pm S E$ of ten observations. The ${ }^{*} \mathrm{p}$ value $<0.05$ was considered statistically significant. 
The regenerated shoots were excised and transferred to half strength LM medium supplemented with various auxins like NAA, IAA and IBA for rooting. Roots were initiated in all the treatments within a week of subculture. Half strength LM medium supplemented with $0.5 \mathrm{mg} / \mathrm{l}$ of NAA was found to be superior to other auxins (Fig. $4 \mathrm{~b}$ ) in producing roots. Thereafter 45 days old culture produced a mean of $10.61 \pm 0.18$ roots per shoot $(100 \%)$ at the concentration of $0.5 \mathrm{mg} / \mathrm{l} \mathrm{NAA}$ with short root length. Above this concentration only callogenesis was observed from the basal region of the microshoots. NAA induced undesirable and uncontrolled formation of callus at the basal region of the plantlets, and roots were shorter and thicker compared with those in lower concentration of NAA medium as previously reported in other woody species (Evers et al. 1988).
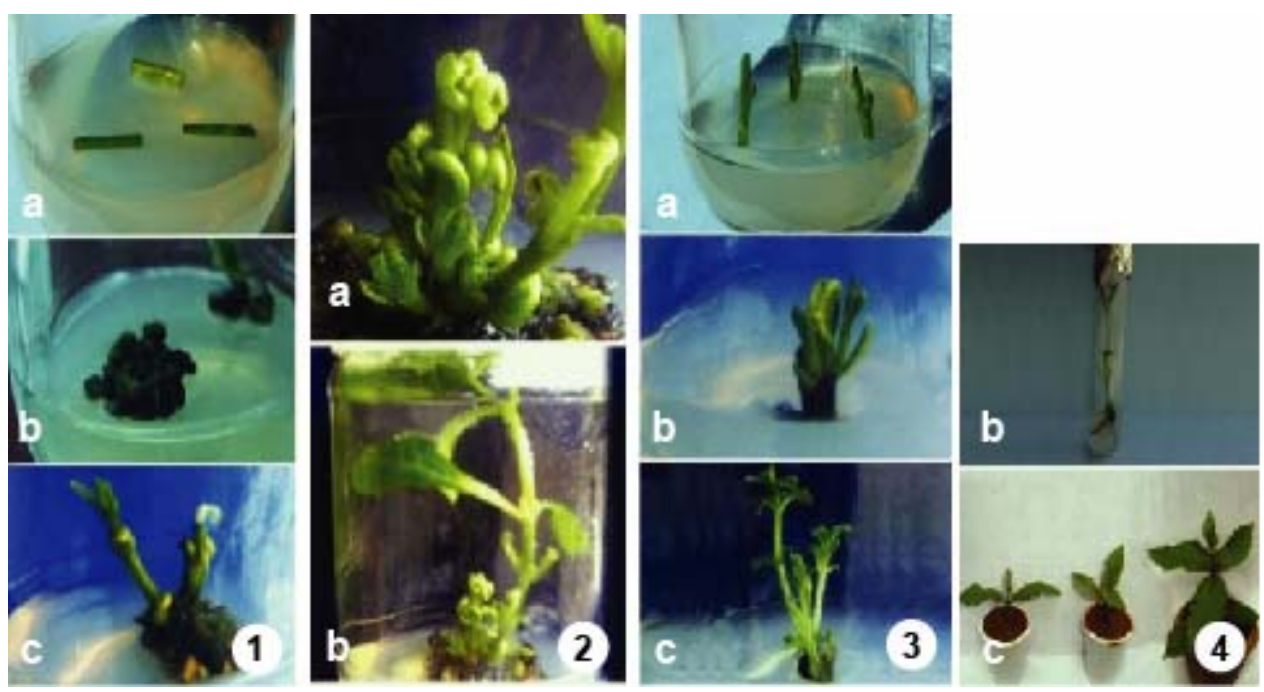

Figs 1-4. Steps involved in regeneration of C. serratum from stem and nodal explants. 1a. Stem internodal explants. 1b. Callus derived from stem internodal explants. 1c. Differention of shoot from the stem callus. 2a. Differentiation of multiple shoots from the stem callus. 2b. Elongation of shoots differentiated from the stem callus. 3a. Nodal explants. 3b. Initiation of shoot buds from the nodal explants. 3c. Elongation of shoots bearing photosynthetic leaves with serrate margins. 4b. Rhizogenesis from excised microshoots. 4c. Hardened potted plantlets of $C$. serratum.

The well rooted intact plantlets were taken out of the culture vessel, dipped in tap water, then transferred to soil and subjected to a hardening process at greenhouse condition for a period of one week at $28^{\circ} \mathrm{C}$ with $90 \%$ humidity. Regenerated plants were successfully acclimated to soil and about $88 \%$ of the regenerants survived under natural condition (Fig. 4c). The morphological characters of in vitro derived plantlets were similar to that of in vivo plants. 
The present study reveals the development of an efficient tissue culture and plant regeneration protocol for C. serratum.

\section{Acknowledgment}

The authors are grateful to the National Educational Society, Shimoga, Karnataka; Sri N.V. Hegde, President, Nitte Education Trust, Nitte; Dr. Nirangan N. Chiplunkar, Principal, NMAMIT Nitte; Dr. C. Vaman Rao, HOD, Department of Biotechnology, NMAMIT, Nitte, Karnataka.

\section{References}

Banarjee SK, Chakravarti RN, Sachdev KS and Vasudev VA (1969) Constituents of root bark of Clerodendrum serratum. Phytochem. 8: 515-518.

Casado JP, Navarro MC, Utrilla MP, Martinez A, and Jimenez J (2002) Micropropagation of Santholina canescens Lagasca and in vtro volatiles production by shoot explants. Plant Cell Tissue Org. Cult. 69: 147-153.

Evers PW, Donkers J, Prat A and Vermeer E (1998) Micropropagation of forest trees through tissue culture. Centre for Agricultural Publishing and Documentation (Pudoc). Wageningen.

Lloyd G and McCown B (1980) Commercially feasible Micropropagation of mountain laurel, Kalmia latifolia by use of shoot tip culture. Int. Plant Prop. Soc. Proc. 30: 421-427.

Maruthi KR, Krishna V, Shankarmurthy K and Rahiman BA (2004) Micropropagation of Cleastrus paniculatus through hypocotyl explants. J. Trop. Med. Plants. 5(2): 249-254.

Mukesh KR, Gaurav K, Shiv KI, Gotmi S and Tripathi DK (2012) Clerodendrum serratum: A clinical approach. Journal of Applied Pharmaceutical Science 2(2): 11-15.

Saldanha CJ and Nicolson DH (1976) Flora of Hassan District, Karnataka. Amerind Publishing Co., New Delhi. 231.

Sharma M, Rai SK , Purshottam DK, Jain M, Chakrabarty D, Awasthi A, Nair KN and Ashok Kumar Sharma (2008) In vitro clonal propagation of Clerodendrum serratum (Linn.) Moon (barangi) : A rare and threatened medicinal plant, Springer. Acta Physiol Plant. DOI 10.1007/s11738-008-0245-4.

Shashikala CM, Shashidhara S and Rajashekharan PE (2005) In vitro regeneration of Centella asiatica L. Plant Cell Biotech. Mol. Biol. 6(1\&2): 53-56.

Vidya SM, Krishna V and Manjunatha BK (2005) Micropropagation of Clerodendrum serratum L. from leaf explants. J. Non-Timber Forest products 12(1): 57-60. 
Vidya SM, Krishna V, Manjunatha BK, Mankani KL, Manzoor A and Jegadeesh singh SD (2007) Evaluation of hepatoprotective activity of Clerodendrum serratum Linn. Indian J. Exp. Biol. 45: 538-542.

Vishwanathan S, Narayanan N, Thirugnanasambantham P, Vijayasekaran V. and Sukumar E (1996) Antinociceptive, anti-inflammatory and antipyretic effects of ethanol extract of Clerodendrum serratum in Experimental animals. J. Ethanopharmacology 65: 237-241.

Xie D and Hong Y (2001) In vitro regeneration of Acacia mangium via organogenesis. Plant Cell Tiss. Org. Cult. 66: 167-173. 